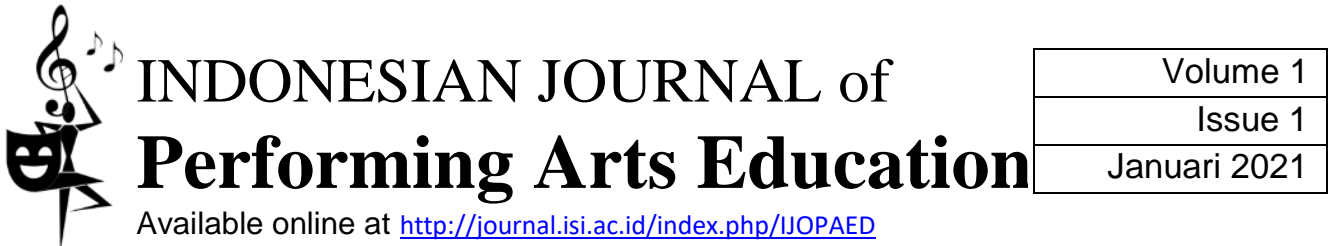

\section{NILAI-NILAI PENDIDIKAN KARAKTER DALAM LANGEN CARITA LAKON PATINE ARYA PENANGSANG}

\author{
Avyana Destyasti Lintang ${ }^{1}$, Sarjiwo ${ }^{2}$, Nur Iswantara ${ }^{3}$ \\ ${ }^{1}$ Institut Seni Indonesia Yogyakarta; destyastiAL97@gmail.com \\ ${ }^{2}$ Institut Seni Indonesia Yogyakarta; sarjiwo@isi.ac.id \\ ${ }^{3}$ Institut Seni Indonesia Yogyakarta; nur.iswantara@isi.ac.id
}

\section{Doc Archive \\ Submited: 03-09-2020 \\ Accepted: 23-12-2020 \\ Published: 31-01-2021 \\ Keywords \\ nilai-nilai pendidikan, pendidikan karakter, langen carita, opera jawa.}

\section{Keywords}

educational values,

character education, Langen Carita, Javanese opera.
Abstrak

Pendidikan karakter di Indonesia sedang diterapkan kembali untuk membentuk siswa memiliki akal pikiran dan budi pekerti dan dapat diajarkan melalui pendidikan seni, salah satunya dalam bentuk opera jawa. Langen carita merupakan salah satu kesenian yang ditujukan untuk membentuk karakter anak sebagai lanjutan pendidikan seni dolanan anak. Langen carita adalah bentuk dari metode sariswara yang di dalamnya terdapat sastra, tembang/lagu/musik/karawitan, cerita dan solah bawa dalam bentuk opera kecil atau sandiwara anak (usia 10-14 tahun). Langen carita juga berkembang sebagai seni pertunjukan dengan banyak cerita sejarah, babad atau kehidupan sehari-hari, salah satunya patine Arya Penangsang. Tujuan penelitian ini adalah mendeskripsikan nilai-nilai pendidikan karakter dalam langen carita lakon Patine Arya Penangsang. Penelitian ini menggunakan metode deskriptif kualitatif dengan mengkaji, menganalisis, mengungkapkan, dan menggambarkan nilai-nilai pendidikan karakter di dalam suatu kesenian. Teknik pengumpulan data menggunakan studi pustaka, wawancara, observasi, dan dokumentasi, yang kemudian divalidasi menggunakan triangulasi. Hasil penelitian menunjukkan bahwa langen carita berjudul Patine Arya Penangsang memiliki nilai-nilai pendidikan karakter religius, toleransi, disiplin, kreatif, cinta tanah air, tanggungjawab, kepemimpinan, percaya diri, pantang menyerah, kerja sama, patuh, tekun, sabar, sopan santun, dan ikhlas dalam unsur drama, tari, dan musik.

\section{Abstract}

Character education in Indonesia is being re-implemented to shape students to have intellect and character and can be taught through art education, one of which is Javanese opera. Langen carita is one of the arts that is intended to shape children's character as a continuation of children's art education. Langen carita is a form of the sariswara method in which there are literature, songs/music/karawitan, stories and solah bawa in short operas or children's plays (ages 10-14 years). Langen carita has also developed as a performing art with many historical stories, chronicles, or daily life, including Patine Arya Penangsang. This study aims to describe the values of character education in the language of the play Patine Arya Penangsang. This research uses a qualitative descriptive method by studying, analyzing, expressing, and describing character education values in performing art. Data collection techniques used literature study, interviews, observation, and documentation, which were then validated using triangulation. The results showed that Langen Carita entitled Patine Arya Penangsang has values of religious character education, tolerance, discipline, creativity, love for the country, responsibility, leadership, self-confidence, never giving up, cooperation, obedience, perseverance, patience, courtesy, and sincere. In the elements of drama, dance, and music. 


\section{Pendahuluan}

Undang-undang Republik Indonesia nomor 20 tahun 2003, tentang sistem pendidikan nasional (UU sisdiknas), pasal 3 menyebutkan bahwa,

Pendidikan nasional berfungsi mengembangkan dan membentuk watak serta peradaban bangsa yang bermartabat dalam rangka mencerdaskan kehidupan bangsa, bertujuan untuk berkembangnya potensi peserta didik agar menjadi manusia yang beriman dan bertakwa kepada Tuhan Yang Maha Esa, berakhlak mulia, sehat, berilmu, cakap, kreatif, mandiri, dan menjadi warga negara yang demokratis serta bertanggungjawab.

Pemerintah melalui Kementerian Pendidikan mulai menggalakkan pendidikan karakter agar peserta didik memiliki kepribadian yang kokoh dan berkarakter kuat. Hal ini diwujudkan dengan diberlakukannya pendidikan berbasis karakter di semua jenjang pendidikan di Indonesia, yang dimulai pada tahun ajaran baru 2011/2012 dan masih diberlakukan hingga saat ini (Aulia, 2011).

Pendidikan karakter dilakukan untuk membentuk moral peserta didik maupun lulusanlulusan dari sekolah untuk membantu membangun bangsa dan negara, tanpa menghilangkan nilai-nilai luhur dan budaya yang sudah ada di masyarakat Indonesia (Sutjipto, 2011). Pendidikan karakter dapat diajarkan sejak anak berusia dini melalui jenjang pendidikan keluarga, PAUD (Pendidikan Anak Usia Dini), sampai ke jenjang perguruan tinggi. Pendidikan karakter dapat diajarkan kepada peserta didik salah satunya melalui pendidikan seni dan budaya.

Fungsi seni sebagai media pendidikan menjadikannya memiliki potensi yang besar untuk membentuk moral anak karena memilki pengaruh yang besar pada perkembangan afektifnya, melalui seni juga peserta didik dapat belajar mengolah rasa dan mengembangkan imajinasinya yang melibatkan domain kognitif, psikomotor, dan afektif (Astuti, 2011, pp. 254258). Kesenian juga menjadi sebagian dari kebudayaan itu sendiri, karena timbul dan tumbuhnya berhubungan dengan jiwa perasaan manusia (Dewantara, 2013, p. 189).

Pendidikan karakter dan budaya melalui pendidikan seni telah dilakukan oleh Ki Hadjar Dewantara sejak beliau mendirikan Perguruan Tamansiswa, hal ini terdapat dalam sengkalan "Ambuka Suwara Angesti Wiji" yang terdapat di tangga Pendapa Tamansiswa, yang artinya membuka suara (menembang, menyanyi, melakukan kesenian), sebagai pepucuk (landasan) daripada angesti wiji (mendidik) (Dewantara, 2013, p. 355). Pendidikan seni merupakan salah satu cara Ki Hadjar Dewantara dalam mengajarkan kepada anak-anak mengenai nilai karakter dan budi pekerti, secara menyenangkan.

Langen carita sendiri merupakan karya Ki Hadi Sukatno untuk anak-anak usia 10-14 tahun, yang mempresentasikan tiga aspek seni yang terintegrasi, yakni seni drama, seni tari dan seni musik sekaligus. Langen carita menjadi menarik karena mengangkat kisah sejarah, babad, atau kehidupan sehari-hari. Lakon Patine Arya Penangsang dipilih karena bercerita mengenai sejarah Arya Penangsang yang gugur saat berperang melawan Sutawijaya dan prajurit Pajang.

Berdasarkan latar belakang tersebut, terdapat ketertarikan terhadap langen carita dilihat dari segi bentuk pertunjukannya, karena terdapat seni drama, tari dan musik. Pemilihan lakon Patine Arya Penangsang sebagai objek penelitian, karena ingin mengetahui dan mendeskripsikan nilai-nilai pendidikan karakter yang ada di dalamnya. Selain itu, cerita Arya Penangsang gugur merupakan salah satu lakon yang dimainkan hanya pada momen tertentu di Tamansiswa seperti misalnya memperingati hari lahir Perguruan Tamansiswa atau pementasan. Lakon Patine Arya Penangsang memiliki jalan cerita yang unik sebagai pendidikan seni untuk membentuk karakter anak karena menceritakan gugurnya Arya Penangsang. Selain itu, fokus penelitian yang akan dilakukan adalah mengkaji ketika proses latihan berlangsung (naskah, tembang, dan tari) dan ketika pementasan langen carita lakon Patine Arya Penangsang.

\section{Metode}

Objek yang diteliti adalah nilai-nilai pendidikan karakter dalam Langen Carita lakon Patine Arya Penangsang. Sumber data pada penelitian ini adalah pengurus dan pamong Taman Kesenian, serta narasumber yang memahami objek yang diteliti. Penelitian bertempat di Pendapa Agung Tamansiswa Yogyakarta.

Proses penelitian pada awalnya diharapkan dapat terjun langsung ke lapangan untuk melihat proses latihan dan interaksi antara pamong dan murid, namun karena kondisi tidak memungkinkan sebab pandemik COVID-19, penelitian dilakukan secara daring melalui aplikasi pesan instan dan wawancara.

Laporan berisi tentang hasil pengumpulan data yang sudah dianalisis, diklasifikasi dan divalidasi, serta menuliskan temuan-temuan 
yang berkaitan dengan objek penelitian mengenai nilai-nilai pendidikan karakter yang terdapat dalam langen carita lakon Patine Arya Penangsang dan yang tidak terdapat dalam 18 nilai pendidikan karakter nasional.

Adapun dalam penelitian ini, sumber data primer didapat dari wawancara. Sumber data sekunder adalah buku yang berhubungan dengan metode sariswara, buku pendidikan, buku tentang seni, kamus, dan dokumentasi.

Instrumen penelitian kualitatif merupakan alat penelitian yang melibatkan peneliti itu sendiri, maka peneliti sebagai instrumen harus divalidasi. Peneliti kualitatif sebagai human instrument, berfungsi menetapkan fokus penelitian, pemilihan informan, melakukan pengumpulan data, menilai kualitas data, menganalisis data, menafsirkan data dan membuat kesimpulan atas segala temuannya (Sugiyono, 2014, p. 222).

Penelitian ini menggunakan triangulasi teknik dan triangulasi sumber, untuk menguji kredibilitas data. Penelitian ini menggunakan metode deskriptif kualitatif dengan teknik analisis data yang digunakan adalah analisis deskriptif kualitatif. Analisis kualitatif merupakan prosedur penelitian yang menghasilkan data deskriptif berupa kata-kata tertulis maupun lisan dari orang-orang atau pelaku yang diamati (Moleong, 2017, p. 3).

\section{Hasil dan Pembahasan}

Berdasarkan hasil wawancara, didapatkan informasi bahwa Taman Kesenian berdiri sejak tahun 1931, ketika pertama kali Tamansiswa bekerjasama dengan pihak Kraton Ngayogyakarta Hadiningrat yang mengajarkan tari beksan kepada pihak luar keraton, yakni para pamong-pamong Tamansiswa.

Pamong-pamong Tamansiswa diajarkan tari oleh guru-guru dari Kridha Beksa Wirama dengan mengajarkan tari Jawa. Maka dari itu, kegunaan Taman Kesenian sejak berdirinya hingga sekarang merupakan tempat untuk belajar seni.

Taman Kesenian dikelola oleh Majelis Luhur Tamansiswa yang dibantu oleh putra wayah (anak cucu/keturunan) guru-guru yang pernah mengajar di Tamansiswa dan berupaya menggali kembali ajaran yang pernah didapat semasa di Perguruan Tamansiswa. Taman Kesenian terbuka untuk umum rentang usia 3,5 tahun hingga usia dewasa.

Materi dasar di Taman Kesenian yang harus diikuti oleh semua siswa pada semua usia adalah tari klasik putri/putra, karawitan dan tembang/macapat/menyanyi. Materi utama di
Taman Kesenian yang diajarkan adalah dolanan anak dan langen carita/sekar. Materi untuk kelas lepas atau dewasa adalah karawitan, tari klasik putra/putri. Taman Kesenian tidak mengadakan sistem ujian, namun ada target pementasan setelah beberapa minggu/bulan latihan reguler. Puncaknya diadakan pentas kolosal bersama yakni Langen Gita.

Langen carita merupakan bentuk sebuah opera kecil atau operet. Langen carita adalah salah satu bentuk pelaksanaan metode sariswara, yang mempunyai tujuan membentuk karakter budi luhur pada anak. Langen carita berisi lagu/musik/karawitan, sastra dan cerita, yang kemudian dibuat cerita baik legenda, fabel, babad maupun cerita para leluhur. Alasan Ki Hadi Sukatno menciptakan langen carita karena memiliki sastra, lagu, dan tari (solah bawa), sebagai pendidikan yang langsung menyentuh anak sejak usia dini, yang kemudian dapat mendidik seseorang menjadi lebih berbudi luhur.

Menurut Majelis Luhur Persatuan Tamansiswa, langen carita pertama kali digubah oleh Ki Sukarso Mangunkawotjo yang menciptakan sandiwara ber-tembang, kemudian pada tahun 1938 muncul gubahan Ki Hadi Sukatno dengan bentuk yang sama dan masa penjajahan Jepang kembali menggubah sandiwara anak-anak dengan irama anak dan lagunya sudah diperpendek supaya lebih mudah memainkannya (1981, pp. 163-164). Langen carita merupakan tingkat lanjutan dari dolanan anak, karena di dalamnya masih terdapat lagu dan permainan, namun sudah disesuaikan untuk anak yang lebih besar, karena adanya penokohan, tembangnya menggunakan kata-kata yang sukar bagi anak-anak yang lebih kecil.

Langen carita yang semula sebagai salah satu pendidikan seni di Tamansiswa berkembang menjadi sebuah hiburan dan dikemas dalam seni pertunjukan. Oleh sebab itu tata rias dan busana, cerita, iringan, dan pemeran tokoh cerita sangat diperhatikan supaya menghasilkan sebuah pementasan yang indah serta memberikan kesan baik kepada penonton yang menyaksikan.

\section{Lakon Patine Arya Penangsang} merupakan gubahan Ki Hadi Sukatno pada masa awal-awal kemerdekaan Indonesia. Cerita ini ditujukan untuk anak-anak umur sekitar 10-14 tahun. Cerita Arya Penangsang diambil dari babad tanah jawi dan serat kanda karena memiliki pola yang mudah dipahami oleh anak, yakni yang jahat kalah dengan yang tidak jahat atau yang hitam kalah dengan yang putih. Pola inilah yang kemudian dipilih untuk menggambarkan gugurnya angkara murka Arya 
Penangsang oleh kebajikan Sutawijaya, oleh karena itu dijadikanlah tema tersebut untuk menggubah lakon Patine Arya Penangsang untuk membentuk karakter anak.

Sebelum pementasan, biasanya dilaksanakan doa bersama yang diikuti pemain dan péngrawit, selain itu disediakan tumpeng sebagai simbol dan harapan keselamatan ketika pementasan berlangsung seperti pada Gambar 1 . Setelah melakukan doa bersama, tumpeng dipotong dan diberikan kepada pemeran Arya Penangsang.

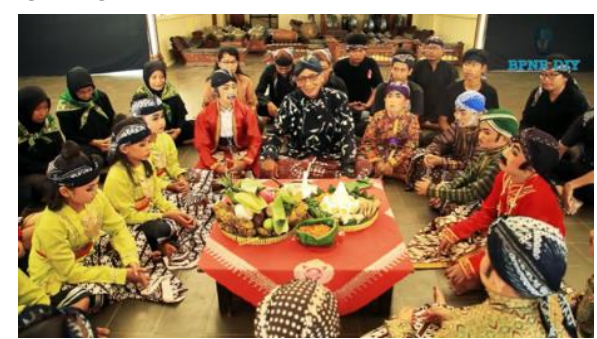

Gambar 1. Tumpengan Sebelum Pementasan

Naskah drama dalam langen carita lakon Patine Arya Penangsang terbagi menjadi dua, yakni struktur dan tekstur drama. Struktur drama dalam Langen Carita lakon Patine Arya Penangsang adalah tema, plot, dan penokohan/karakterisasi. Tekstur drama adalah dialog, mood/suasana, dan spectacle.

Langen carita lakon Patine Arya Penangsang menggunakan tari sebagai pendukung cerita dan pertunjukan. Setelah itu pamong menjelaskan nama dan tujuan geraknya. Gerak-gerak yang digunakan lebih pada gerakan untuk tari putra, karena semua tokohnya adalah laki-laki jadi gerakannya pun gagah. Sebagai contoh gerakan ketika berperang untuk tokoh gagah (Arya Penangsang dan Sutawijaya), dan gerakan sembahan untuk setiap tokoh alus maupun gagah (prajurit Jipang, Patih Metaun, Sutawijaya dan para patih Pajang).

Keseluruhan tembang dalam naskah langen carita lakon Patine Arya Penangsang dinyanyikan dalam Laras Sléndro dan Barang Miring dengan iringan gamelan sebagai musik pengiringnya dan menggunakan notasi sariswara khusus untuk lagunya, bukan iringannya. Dalam proses latihan, pertama kali yang dilakukan oleh pamong adalah meminta anak untuk menirukan pamong melagukan karena tidak semua anak bisa membaca notasi sariswara. Dengan cara tersebut anak terbiasa mendengar bunyi nada dan cara menyanyikannya. Pamong melagukan per bait lagu dan ditirukan anak sampai bisa menyanyikan dengan benar dan hafal dengan diulang terus-menerus. Ketika mulai bernyanyi ada aba-aba menggunakan képrak untuk mempermudah anak bernyanyi atau mengubah irama iringan. Tembangnya menggunakan notasi sariswara yang berbeda dari notasi kepatihan, sebagai contoh seperti pada Gambar 2.

$$
\begin{aligned}
& \text { Lagu } 1 \\
& \text { Laras Sléndro, } 1 \text { = Lima } \\
& \text { _ Dj } 4 \text { jjjk! kj Dj \$ jjjk! Â kj Dj } 4 \text { jj! @5! } \hat{A} \\
& \text { Â pj } 4 \text { jjjk! kj pj \$ jjjk! Â kj pj } 4 \text { jj! @5 jj } 0 \text { Â }
\end{aligned}
$$

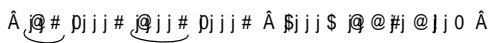

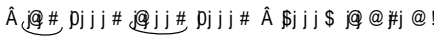

Gambar 2. Notasi Témbang/Lagu 1

Sariswara bisa diibaratkan seperti tangga nada dalam musik barat, yang penulisannya sama dalam tangga nada apapun (1-2-3-4-5-6-7), jadi tidak kesulitan ketika harus mengganti tinggi, rendahnya nada.

Langen carita lakon Patine Arya Penangsang seluruhnya menggunakan bahasa Jawa sebagai dialognya. Naskah drama langen carita lakon Patine Arya Penangsang ditulis dan dibukukan pada tahun 1964 dengan ejaan Soewandi. Naskah tersebut ketika dipentaskan dapat dikurangi atau dipotong untuk memenuhi durasi yang diinginkan tanpa menghilangkan garis besar cerita yang dibawakan.

Struktur dalam naskah langen carita lakon Patine Arya Penangsang terdiri dari: (1) Tema, yaitu musnahnya angkara murka tokoh Arya Penangsang oleh kebajikan tokoh Sutawijaya. Tema ini diambil dari pola yang jahat kalah dengan yang baik; (2) Plot, adalah yang menentukan hubungan peran yang harus dibawakan, terbagi pada bagian awal, tengah dan akhir. Pemeran merupakan sumber terciptanya peristiwa-peristiwa yang terjadi (Iswantara, 2016, p. 193); (3) Penokohan, karakter yang menjadi penggerak jalan cerita. Karakter ini berpribadi, berwatak, dan memiliki sifat-sifat berkarakteristik yang tiga dimensional, yakni fisiologis, sosiologis, dan psikologis (Iswantara, 2016, p193). Selain itu, penokohan juga menggunakan fungsi psikis dalam dramaturgi seperti Protagonist, Antagonist, Tritagonist, dan Utility (Harymawan, 1993, pp. 22-26). Lebih lengkap susunan tokoh dapat dilihat pada Tabel 1. 
Tabel 1. Tabel Pemeranan Lakon Patine Arya Penangsang

\begin{tabular}{|c|c|c|c|c|}
\hline Nama & Penokohan & Psikologis & Sosiolo-gis & Fisiologis \\
\hline Arya Penangsang & Antagonis & $\begin{array}{l}\text { Tangguh } \\
\text { Pemberani } \\
\text { Pantang menyerah } \\
\text { Tidak sabaran } \\
\text { Keras kepala } \\
\end{array}$ & $\begin{array}{l}\text { Orang yang memiliki status sosial } \\
\text { tinggi, raja Jipang }\end{array}$ & $\begin{array}{l}\text { Laki-laki Bersuara lantang } \\
\text { Gagah } \\
\text { Umur } 30 \text { tahunan }\end{array}$ \\
\hline Sutawijaya & Protagonis & $\begin{array}{l}\text { Cerdik } \\
\text { Pemberani } \\
\text { Tangguh } \\
\text { Pantang menyerah }\end{array}$ & $\begin{array}{l}\text { Orang memiliki status sosial } \\
\text { sedang, anak Ki Pemanahan }\end{array}$ & $\begin{array}{l}\text { Laki-laki } \\
\text { Bersuara teduh } \\
\text { Umur } 20 \text { tahunan }\end{array}$ \\
\hline Patih Metaun & Antagonis & $\begin{array}{l}\text { Setia } \\
\text { Sabar } \\
\text { Patuh }\end{array}$ & $\begin{array}{l}\text { Orang memiliki status sosial } \\
\text { sedang, Patih Arya Penangsang }\end{array}$ & $\begin{array}{l}\text { Laki-laki Tua } \\
\text { Umur } 40 \text { tahunan }\end{array}$ \\
\hline Ki Pemanahan & Protagonis & $\begin{array}{l}\text { Patuh } \\
\text { Pemberani }\end{array}$ & $\begin{array}{l}\text { Orang berekonomi sedang, Patih } \\
\text { sultan Pajang }\end{array}$ & Laki-laki Umur 40 tahunan \\
\hline Ki Juru Martani & Protagonis & $\begin{array}{l}\text { Cerdik } \\
\text { Pemberani }\end{array}$ & $\begin{array}{l}\text { Orang memiliki status sosial } \\
\text { sedang, saudara Ki Pemanahan }\end{array}$ & $\begin{array}{l}\text { Laki-laki } \\
\text { Tua } \\
\text { Umur } 40 \text { tahunan }\end{array}$ \\
\hline Ki Ageng Penjawi & Protagonis & $\begin{array}{l}\text { Patuh } \\
\text { Pemberani }\end{array}$ & $\begin{array}{l}\text { Orang memiliki status sosial } \\
\text { sedang, satu guru dengan Ki } \\
\text { Pemanahan dan utusan sultan } \\
\text { Pajang }\end{array}$ & $\begin{array}{l}\text { Laki-laki Tua } \\
\text { Umur } \\
40 \text { tahunan }\end{array}$ \\
\hline Pekathik & Utility & Patuh & $\begin{array}{l}\text { Orang memiliki status sosial } \\
\text { rendah, pengurus kuda raja }\end{array}$ & $\begin{array}{l}\text { Laki-laki } \\
\text { Muda } \\
\text { tegap }\end{array}$ \\
\hline Wadyabala Sareng & Utility & $\begin{array}{l}\text { Patuh } \\
\text { Setia }\end{array}$ & $\begin{array}{l}\text { Orang memiliki status sosial } \\
\text { sedang, prajurit Jipang }\end{array}$ & $\begin{array}{l}\text { Perempuan } \\
\text { Bertubuh tinggi } \\
\text { Umur } 20 \text { tahunan }\end{array}$ \\
\hline $\begin{array}{l}\text { Wadyabala Pajang } \\
\text { Sareng }\end{array}$ & Utility & $\begin{array}{l}\text { Patuh } \\
\text { Pemberani }\end{array}$ & $\begin{array}{l}\text { Orang memiliki status sosial } \\
\text { sedang, prajurit Pajang }\end{array}$ & $\begin{array}{l}\text { Perempuan dan laki-laki } \\
\text { Umur } \\
20 \text { tahunan }\end{array}$ \\
\hline
\end{tabular}

Tekstur dalam naskah langen carita lakon Patine Arya Penangsang terdiri dari: (1) Dialog, ditinjau dari segi estetis naskah dialog dinyanyikan sesuai suasana tiap adegan yang sedang berlangsung. Segi teknis, pemberian catatan pengucapan dan alur yang ditulis dalam format berbeda; (2) Spectacle, adalah aspekaspek visual yang terdapat dalam sebuah lakon, terutama aksi fisik dari tokoh-tokoh yang memerankan di atas panggung (Hidayahtulloh \& Saksono, 2017, p. 3). Pembahasan di sini lebih menekankan dari segi tata kostum, tata rias, tata lampu, dan hand property; (3) Mood/suasana, hal ini dapat dilihat pada dialog, gerak tubuh, spectacle dan respon terhadap pemain lainnya (Jiwangga, 2018, p. 18). Semisal suasana tegang dan amarah.

Dalam pementasan lakon Patine Arya Penangsang, tata kostum yang digunakan adalah tipe kostum historis, karena dibuat sama seperti zaman kerajaan. Tata rias dan busana menggunakan kostum gaya Mataraman atau Jogja. Rias tokoh untuk membedakan tiap karakter wajah sesuai dengan tokoh peranan. Tata cahaya tergantung pada waktu pementasan, karena pementasan lakon ini bertempat di pendapa terbuka. Maka tata cahaya lebih bersifat untuk menerangi secara merata, jika pementasan diadakan pada siang hari maka cahayanya mengandalkan cahaya matahari.
Penangsang juga tidak menggunakan dekorasi, hanya menggunakan bentuk asli pendapa yang sudah jadi. Maka dari itu pementasan Langen Carita lakon Patine Arya Penangsang lebih banyak menggunakan hand property. Sebagai contoh properti tombak yang digunakan oleh prajurit Pajang dan Sutawijaya. Gambar 3 menunjukkan tata cahaya pementasan pada siang hari dan Gambar 4 pada waktu malam hari.

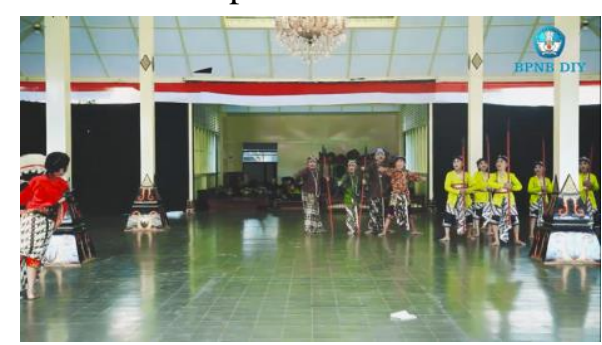

Gambar 3. Tata Cahaya Pementasan Siang Hari

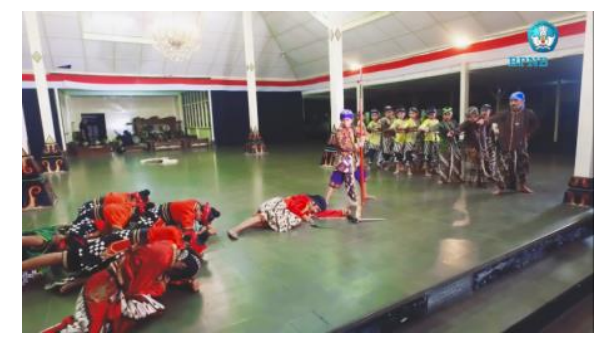

Gambar 4. Tata Cahaya Pementasan Malam Hari 
Langen carita lakon Patine Arya Penangsang merupakan bentuk representasi dari cerita yang sudah ada atau dramatari yang memiliki tokoh di dalamnya. Langen carita adalah solah bawa yang berwujud perilaku tenaga yang ditata berdasarkan irama lagu (Sukatno, 1964, p. 25). Ragam gerak tari dalam langen carita lakon Patine Arya Penangsang menggunakan motif ragam gerak jawa tari putra. karena semua tokoh yang ada dalam naskahnya adalah laki-laki, sehingga ragam gerak yang digunakan juga untuk tari putra walaupun diperankan oleh perempuan.

$$
\text { Sedangkan untuk tembang }
$$

menggunakan Laras Sléndro dan Barang Miring, yang diajarkan menggunakan sariswara. Ketika mempelajari sariswara biasanya menggunakan bantuan saron atau suling (Sukatno, 1964, p. 5). Lagu-lagu yang digunakan dalam langen carita rata-rata jalannya irama sedang (cukupan). Lagu dan syair (kata) dalam hal ini penting sekali, intinya tidak boleh sampai melambat dan terlalu banyak cengkok, ucapan kata-katanya harus jelas.

Ketika menyenyikan tembang, Taman Kesenian thinthingan-nya menggunakan gender dengan menggunakan pemukul peking, sehingga suaranya lebih nyaring. Selain thinthingan, ada pula aba-aba yang menggunakan keprak. Keprak digunakan untuk menuntun jalannya irama, mengangkat awalan tembang, membuat suasana ketika adegan menuju perang, atau untuk memberi aba-aba memelankan atau mempercepat irama (Sukatno, 1964, p. 27).

$$
\text { Dalam Majelis Luhur Persatuan }
$$

Tamansiswa, Sariswara sendiri merupakan penulisan notasi ciptaan Ki Hadjar Dewantara dengan mengadaptasi sistem notasi barat, yakni metode "chevé-methode", yaitu metode bernyanyi dengan menggunakan do-re-mi yang kemudian diadaptasi menggunakan nada pentatonis pada gamelan jawa yakni Sléndro dan Pélog, dan dituliskan menggunakan notasi sistem sariswara (Dewantara, 1941, p. 2). Contoh notasi dapat dilihat pada Tabel 2.

Tabel 2. Notasi Kepatihan ditulis Menggunakan Notasi Sariswara

\begin{tabular}{lll}
\hline Phatet & Kepatihan & Sariswara \\
\hline Sléndro Phatet Sanga & t y 12356 ! @ & 12345 ! @ \# \$ \\
\hline Sléndro Pathet Manyura & y 12356 ! @ \# & 12345 ! @ \# \$ \\
\hline Sléndro Pathet Nem & 2356 ! @ \# & 12345 ! @ \# \$ \\
\hline
\end{tabular}

Tembang dalam langen carita lakon Patine Arya Penangsang mengambil piridan (pembelajaran yang diambil isinya atau maknanya) dari tembang macapat, salah satunya tembang Megatruh yang diambil watak lagunya yakni kecewa, sedih, prihatin dalam lagu 9, laras Sléndro, $1=$ Lima. Gambar 5 adalah bentuk notasi tersebut.

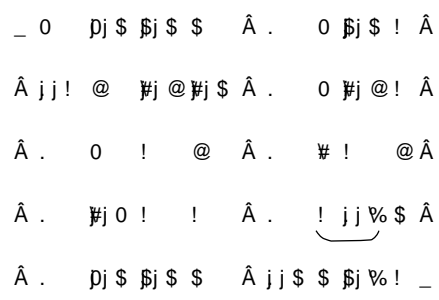

Gambar 5. Notasi Tembang/Lagu 9

Nilai-nilai pendidikan karakter dalam langen carita lakon Patine Arya Penangsang pada unsur drama, tari dan musik dapat dilihat juga dari proses latihan dan pementasan. Pendidikan karakter ini diharapkan tertanam pada diri anak sebagai bekal hingga dirinya dewasa nanti. Melalui wiraga anak dilatih untuk melihat visual ketika menarikan gerak yang ada di dalam lakon, kemudian mendengarkan audio melalui tembang yang dinyanyikan dan iringan gamelan yang melatih kepekaan sang anak.

Melalui wirasa anak akan berlatih merasakan apa yang telah ia terima dari pancaindranya melalui wiraga dengan batiniahnya. Anak akan melatih kehalusan dalam dirinya, misalnya belajar sabar, tidak pantang menyerah dan sebagainya, guna membentuk dirinya sendiri. Melalui wiraga dan wirasa, wadah dalam diri anak terbentuk wirama atau perilaku hidupnya. Wirama yang telah tertanam dalam diri sejak kecil melalui pendidikan seni untuk membentuk karakternya. Perilaku hidup ini akan terlihat ketika sudah dewasa, bagaimana anak menjalankan kehidupan berdasarkan pendidikan yang telah terima sejak kecil, sehingga hidupnya tidak kehilangan arah dan pribadinya terbentuk.

Nilai-nilai pendidikan karakter yang terdapat dalam langen carita lakon Patine Arya Penangsang diantaranya.

1. Religius, berdoa sebelum memulai dan mengakhiri latihan.

2. Toleransi, terbagi menjadi dua bagian, yakni saling menghargai, menghargai temannya yang lain ketika tidak bisa nembang atau 
melakukan solah bawa dan tepa salira, menghargai temannya yang lain dan membantu mengajarkan temannya yang belum bisa nembang atau melakukan solah bawa.

3. Disiplin, berlatih dengan bersungguhsungguh dan tidak membuang waktu. Terkadang anak terlalu asik bermain, namun ketika berlatih kembali sudah siap serius dan melakukan dengan baik.

4. Kreatif, anak bersama-sama membuat aksesoris tari dan mengecat hand property kuda dengan bimbingan pamong. Hal ini membuat anak belajar sesuatu yang indah dan berkhayal, bagaimana membuat atau mewarnainya, dan hal ini yang memicu kreativitas anak.

5. Cinta tanah air, terdapat pada tekstur drama, yakni dialog. Dilihat dari adegan Arya Penangsang ingin membela tanah Jipang dari serbuan prajurit Pajang yang menantangnya. Hal ini disebabkan karena Arya Penangsang berniat menguasai Pajang, sehingga Sultan Agung tidak tinggal diam dengan mengirim suruhannya ke Jipang. Terdapat pada musik, yakni dialog tembang yang liriknya sama persis dengan dialog.

6. Bertanggungjawab, anak berhasil memerankan tokoh yang diberikan padanya dengan baik dan sesuai karakter dari tokohnya.

7. Kepemimpinan, anak belajar memimpin teman-temannya untuk berdoa bersama. Biasanya secara bergantian dengan suka rela atau ditunjuk oleh pamong.

8. Percaya diri, anak dilatih untuk tidak malu menunjukkan kemampuannya pada orang lain.

9. Pantang menyerah, terdapat pada struktur drama yakni tema, dan struktur drama yakni dialog. Dilihat dari adegan Arya Penangsang bangkit berdiri setelah tertusuk tombak, menyerang prajurit Pajang dan Sutawijaya. Unsur tari dapat dilihat pada solah bawa dialog Arya Penangsang (Ngebyuka bareng sakethi), bangun, menendang kearah prajurit Pajang dan Sutawijaya dengan level rendah, sedang, dan tinggi. Unsur musik terdapat pada lirik lagu yang sama dengan dialog.

10. Kerja sama, menyiapkan properti dan naskah yang digunakan untuk latihan bersama-sama. Unsur drama, pasukan Pajang dan para Patih bersiap di pingir sungai Bengawan. Unsur tari dilihat dari solah bawa prajurit Pajang yang membawa tombak sambil berjalan. Unsur musik terdapat pada lirik tembang.
11.Patuh, dilihat dari unsur drama, terdapat pada adegan prajurit Jipang yang menghadap Arya Penangsang. Unsur tari dilihat dari solah bawa prajurit ketika berbicara dan menghadap Arya Penangsang. Unsur musik terdapat pada lirik tembang.

12. Tekun, latihan dengan sungguh-sungguh dan berlanjut, karena membutuhkan proses.

13. Sabar, dilihat dari unsur drama, terdapat pada adegan Patih Metaun menahan kaki Arya Penangsang supaya tidak tergesa-gesa melawan pasukan Pajang sendirian. Unsur tari dilihat dari solah bawa Patih Metaun yang menahan kaki Arya Penangsang dalam level rendah. Unsur musik terdapat pada lirik tembang.

14. Sopan santun, dilihat dari unsur drama, adegan Patih Metaun yang melakukan gerak sembahan setiap akan berbicara pada Arya Penangsang. Unsur tari filihat dari solah bawa Patih Metaun yang melakukan sembahan setiap akan berbicara dengan Arya Penangsang, menggunakan ruang level rendah (berlutut) dan level tinggi (berdiri). Unsur musik terdapat pada lirik tembang.

15. Ikhlas, terdapat pada pementasan setelah anak merelakan dirinya mendalami karakter setiap tokoh yang dan melaksanakannya dengan baik hingga pementasan selesai.

\section{Kesimpulan}

Langen carita lakon Patine Arya Penangsang dapat dilihat dari ketika proses latihan dan pementasan dalam unsur drama, tari, dan musiknya. Nilai-nilai pendidikan yang sudah ditemukan selama penelitian adalah religius, toleransi (saling menghargai dan tepa salira), disiplin, kreatif, cinta tanah air, tanggungjawab, kepemimpinan, percaya diri, pantang menyerah, kerja sama, patuh, tekun, sabar, sopan santun dan ikhlas. Pendidikan karakter melalui metode Sariswara dalam bentuk langen carita lakon Patine Arya Penangsang digunakan Tamansiswa untuk membentuk karakter anak, menajamkan pancaindranya melalui seni, menghaluskan perasaannya, dan memberikan pembelajaran yang diharapkan terus membekas diingatan anak untuk bekal hidupnya nanti.

Nilai-nilai pendidikan karakter yang memiliki ketiga unsur seni pertunjukan (drama, tari, dan musik) dalam penelitian ini adalah nilai pendidikan karakter pantang menyerah, kerja sama, patuh, sabar, dan sopan santun. Unsur drama dilihat dari struktur drama yakni tema dan tekstur drama (dialog). Unsur tari dilihat dari solah bawa para pemain yang mengikuti 
tembang. Unsur musik dilihat dari tembang yang liriknya berasal dari dialog. Nilai pendidikan karakter yang hanya memiliki dua unsur (drama dan musik) adalah nilai pendidikan karakter cinta tanah air. Unsur drama dilihat dari tekstur naskah drama yakni dialog. Unsur musik dilihat dari tembang yang liriknya sama dengan dialog. Sedangkan nilai-nilai pendidikan karakter lainnya terdapat pada latihan dan pementasan. Nilai pendidikan karakter toleransi memiliki bagian untuk karakter saling menghargai dan tepa salira, keduanya disatukan karena memiliki pengertian yang sama.

Langen carita lakon Patine Arya

Penangsang diharapkan lebih diperkenalkan lagi sebagai salah satu pendidikan seni untuk membentuk karakter anak. Karena dalam langen carita terdapat metode sariswara yang digunakan untuk membentuk karakter sejak usia dini. Pembentukan karakter melalui lakon Patine Arya Penangsang, anak belajar dengan gembira dan tidak merasa tertekan, serta tetap terus melestarikan dan mengajarkan langen carita. Melalui penelitian ini, diharapkan masyarakat, pendidik, maupun peneliti dapat membahas lebih lanjut dan dapat mengembangkan unsur-unsur yang terdapat dalam langen carita atau opera jawa.

\section{Referensi}

Astuti, K. S. (2011). Pengembangan Model Pembelajaran Karakter Berbasis Seni. In D. Zuchdi (Ed.), Pendidikan Karakter, Dalam Perspektif Teori dan Praktik (pp. 244-273). Yogyakarta: UNY Press.

Aulia, L. (2011). Pemerintah Canangkan Pendidikan Karakter. Retrieved from Kompas website: https://nasional.kompas.com/read/2011/07/13/04580874/pemerintah.canangkan.pendidikan.karak ter

Dewantara, H. (1941, April). Metode Sari-swara dan Bedanya dengan Kepatihanschrift. Poesara.

Dewantara, H. (2013). Karya Ki Hadjar Dewantara: Pendidikan (Bagian pertama). Yogyakarta: UST Press.

Harymawan, R. M. A. (1993). Dramaturgi. Bandung: Remaja Rosdakarya.

Hidayahtulloh, P., \& Saksono, L. (2017). Struktur Dan Tekstur Drama Kabaleund Liebe Karya Friedrich Schiller. Identitaet, 6(2), 1-5. Retrieved from https://jurnalmahasiswa.unesa.ac.id/index.php/identitaet/article/viewFile/19230/17560

Iswantara, N. (2016). Drama Teori dan Praktik Seni Peran. Yogyakarta: Media Kreatifa.

Jiwangga, J. B. J. (2018). Analisis Struktur dan Tekstur Drama dalam Naskah serta Video Pementasan Mega-Mega Karya Arifin C. Noer (Universitas Sanata Dharma). Retrieved from https://repository.usd.ac.id/31537/

Majelis Luhur Tamansiswa. (1981). Tamansiswa 30 Tahun. Yogyakarta: Percetakan Tamansiswa.

Moleong, L. J. (2017). Metode Penelitian Kualitatif. Bandung: Remaja Rosdakarya.

Sugiyono, S. (2014). Metode Penelitian Penelitian Kuantitatif, Kualitatif dan R\&D. Bandung: Alfabeta.

Sukatno, H. (1964). Langen Tjarita Patine Arya Penangsang. Yogyakarta: Percetakan Tamansiswa.

Sutjipto, S. (2011). Rintisan Pengembangan Pendidikan Karakter di Satuan Pendidikan. Jurnal Pendidikan Dan Kebudayaan, 17(5), 501-524. https://doi.org/10.24832/jpnk.v17i5.45 